TECHNICAL TRANSACTIONS 5/2017

CZASOPISMO TECHNICZNE 5/2017

MECHANICS

DOI: $10.4467 / 2353737 X C T .17 .076 .6433$

\begin{abstract}
Jerzy Kamieński (jkamien@usk.pk.edy.pl)
Institute of Thermal and Process Engineering, Faculty of Mechanical Engineering,

Cracow University of Technology
\end{abstract}

\author{
Stanisław Spytkowski \\ Miejski Zakład Wodociągów i Kanalizacji, Nowy Targ
}

\title{
GAS DISPERSION AND SOLID SUSPENSION IN LIQUID \\ BY INDEPENDENTLY DRIVEN IMPELLERS
}

\section{DYSPERGOWANIE GAZU I CIAŁA STAŁEGO W CIECZY \\ PRZEZ NIEZALEŻNIE NAPĘDZANE MIESZADŁA}

\begin{abstract}
Critical impeller rotational speeds for having a solid suspension in a liquid and for gas dispersion in the slim vessel with two independently driven impellers were determined. An A-315 impeller functioned as the lower impeller whereas a Rushton turbine was fixed higher with gas being fed right below the latter. We investigated what influence on this rotational speed was had by the distance between the impellers, their rotational direction, solid concentration, solid particle size and gas flow rate. Results obtained for the twoand three-phase systems were compared. In the three-phase systems, we also measured the power input in order to assess the efficiency of mixing.
\end{abstract}

Keywords: mixing, two- and three-phase systems

\section{Streszczenie}

Wyznaczono częstości obrotów mieszadeł, przy jakich wytwarzana jest zawiesina ciała stałego w cieczy i dyspergowany jest $\mathrm{w}$ niej gaz, $\mathrm{w}$ aparacie $\mathrm{z}$ dwoma oddzielnie napędzanymi mieszadłami. Dolnym mieszadłem było A-315, górnym, pod które wprowadzano gaz, turbinowe tarczowe. Zbadano, jaki wpływ na te częstości ma odległość między mieszadłami, kierunki ich obrotów, stężenie i wielkość cząstek ciała stałego oraz wydatek gazu. Porównano wyniki uzyskane w układach dwu i trójfazowych. W tych ostatnich zmierzono także nakłady mocy, pozwalające ocenić efektywność mieszania.

Słowa kluczowe: mieszanie, układy dwufazowe i trójfazowe 


\section{Introduction}

Producing tree-phase liquid-gas-solid systems is difficult. There are no impellers, which could suspend solid particles in a liquid, as well as disperse gas in it. Impellers generating axial flow are useful for making a suspension, while badly dispersing gas. Radial flow impellers dedicated for gas-liquid are not very effective for solid suspension.

This work offers a solution with two independently driven impellers, an A-315 impeller in the lower positions is used for moving solid particles from the vessel bottom and for suspending them in a liquid, and the upper Rushton turbine impeller for gas dispersion is introduced directly below the impeller. The independent impellers drive makes it possible to diversify their speed and rotation sense.

This solution was previously investigated for liquid-solid [1, 2], and gas-liquid systems $[3,4]$. The obtained results determine the influence of the second impeller for solid suspension or gas dispersion.

\section{Mixing equipment and methodology}

Experiments were conducted in cylindrical vessels $D=0.288 \mathrm{~m}$, with four standard baffles $D / 10$, mixture level $H=2 D$. The vessel had a cone bottom cartridge - Fig. 1 . The lower impeller A315 was located at $h=d$ form the bottom, while the upper Rushton turbine at $\Delta h=(1.5-3)$ $d$ from the lower impeller. The impeller diameter was $d=D / 3$. The solid phase consisted of agalite particles with the average diameter of $d_{s}=0.58 \mathrm{~mm}$ and $0.83 \mathrm{~mm}$, density $2315 \mathrm{~kg} / \mathrm{m}^{3}$. The liquid phase was water, and the gas phase - air. The solid concentration range was varied in the range of $c_{m}=0.02-0.05 \mathrm{~kg} / \mathrm{kg}$. The maximum gas flow rate was $q=10^{-4} \mathrm{~m}^{3} / \mathrm{s}$.

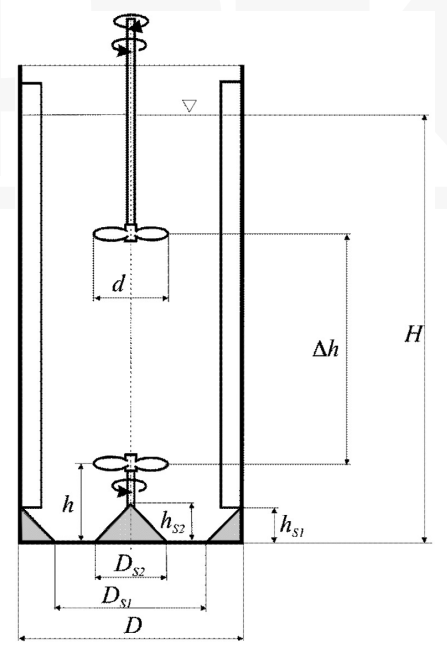

Fig. 1. Vessel geometry. $D_{s 1}=0.8 D, D_{s 2}=0.3 D, h_{s 2}=0.2 D$ 
Finding the minimum impeller rotational speed of each impeller, which would guarantee solid suspension and gas dispersion in a mixture, was the aim of the study. The impeller rotational speed, called the critical impeller speed, was determined by visual observations, using an endoscope and an ultra high-speed Olympus camera.

As critical impeller speed for the lower A-315 impeller were assumed lowest rotational speeds at which all solid particles were already in motion, were taken from vessel bottom or were moving on it. Visual observation was conducted with a run by an endoscope, situated at a distance of $80 \mathrm{~mm}$ from the vessel axis, at half the diameter, between the neighbouring baffles.

As critical impeller speeds for the upper - Rusthon turbine impeller were taken minimum impeller rotational speeds needed to disperse the added gas in the whole vessel volume, at which gas bubbles penetrated through to the bottom.

\section{Measurement results}

The previously conducted measurements of the two-phase solid-liquid systems determined the critical impeller speed for the lower impeller $n_{D}{ }^{(s)}$ at which a complete suspension was produced $[1,2,5]$, and for two phase gas-liquid mixture critical impeller speed $n_{G}{ }_{G}{ }^{(g)}$ needed for full dispersion, at which gas bubbles penetrated through to the vessel bottom $[3,4,5]$, in conditions when both impellers were working. Measurement results were processed as dimensionless equations, where the rotational speeds were related to appropriate critical speeds, occurring when the second impeller was not used:

$$
\begin{aligned}
& \frac{n_{D}^{(s)}}{n_{D 1}^{(s)}}=1-C_{1} \cdot F r_{G}^{\mathrm{a}_{1}} \cdot c_{m}^{\mathrm{a}_{2}} \cdot\left(\frac{\Delta h}{d}\right)^{\mathrm{a}_{3}} \cdot\left(\frac{d_{s}}{d}\right)^{\mathrm{a}_{4}} \\
& \frac{n_{G}^{(g)}}{n_{G 1}^{(g)}}=1-C_{2} \cdot F r_{D}^{\mathrm{b}_{1}} \cdot R e_{g}^{\mathrm{b}_{2}} \cdot\left(\frac{\Delta h+1}{d}\right)^{\mathrm{b}_{3}}
\end{aligned}
$$

where:

$$
F r_{G 1}=\frac{n_{G 1}^{2} \cdot d}{g}=0.380 \cdot R e_{g}^{0.0935} \cdot\left(\frac{\Delta h}{d}+1\right)^{0.715}
$$

Table 1. Constant and exponent values for Equations (1) and (2)

\begin{tabular}{|c|c|c|c|c|c|c|c|c|c|}
\hline $\begin{array}{c}\text { Direction of } \\
\text { impeller rotation }\end{array}$ & $C_{1}$ & $a_{1}$ & $a_{2}$ & $a_{3}$ & $a_{4}$ & $C_{2}$ & $b_{1}$ & $b_{2}$ & $b_{3}$ \\
\hline consistent & $c_{m}-0.045$ & 1.21 & 0 & $73.56 c_{m}-3.25$ & -0.60 & 5.48 & 0.72 & -0.096 & -1.97 \\
\hline adverse & 0.17 & 0.60 & 1.39 & -0.28 & -0.94 & 1.44 & 0.61 & -0.13 & -0.67 \\
\hline
\end{tabular}

In a system with two independently driven impellers, each of them has another role. The lower one raises the solid from the bottom making its suspension, while the other one disperses a gas delivered bellow it. Measurements of mixing the two-phase system: solid-liquid and gas-liquid showed that, usually, the upper impeller supported the transport 
of solid particles made by the lower impeller into upper areas of the vessel, whereas the lower impeller assisted gas dispersion, which the upper impeller was responsible for. In case of mixing a three-phase system, both impellers serve an equally important function.

a)

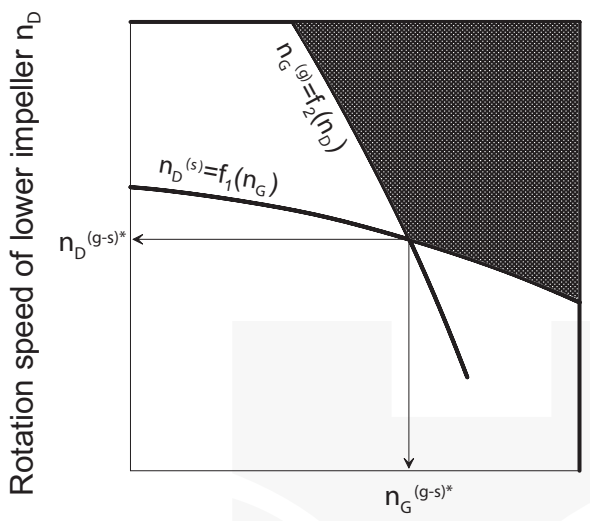

Rotation speed of upper impeller $n_{G}$ b)

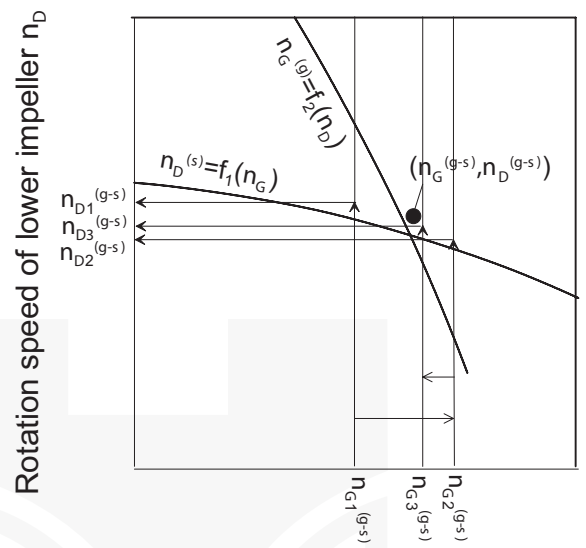

Rotation speed of upper impeller $n_{G}$

Fig. 2. Critical rotational speed of impeller if: a) there is no influence, b) dispersed phases influence each other

If the presence of the second dispersed phase in a liquid has no influence on mixing, then the rotational speed for a three-phase system can be found from equations describing the critical impeller speed: lower impeller $n_{D}^{(s)}(1)$ and upper impeller $n_{G}{ }^{(g)}(2)$. It was shown in Fig. 2a, as coordinates of the point of intersection of curves showed by equations $n_{D}{ }^{(s)}=f_{1}\left(n_{G}\right)$ and $n_{G}{ }^{(g)}=f_{2}\left(n_{D}\right)$ (for pre-set: $\Delta h, c_{m}, d_{s}$ i $q$ ). A fully dispersed three-phase system would come into existence at impeller rotational speed being in the darkened part of the graph, for $n_{D} \geq n_{D}{ }^{(s)}=f_{1}\left(n_{G}\right)$ and $n_{G} \geq n_{G}{ }^{(g)}=f_{2}\left(n_{D}\right)$. As shown, such a mixture can be made for the upper impeller rotational speed $n_{G}<n_{G}{ }^{(g s)^{*}}$ (to the left from the intersection point) and higher speed of the lower impeller $n_{D}>n_{D}{ }^{(s)}$, as well as at $n_{D}<n_{D}{ }^{(g-s)^{*}}$, where $n_{G}>n_{G}{ }^{(g)}$ (to the right of this point).

Every change of the rotational speed of one impeller causes a change of the dispersing state not only in the dispersed phase, but also in the second phase. Then, it is necessary to change the rotational speed of the second impeller, and the situation repeats itself. Then, it is possible to experimentally find the critical impeller speed only with a certain approximation.

The procedure of the study is shown in Fig. 2b. In the first approximation, the upper impeller critical rotational speed was accepted $n_{G 1}{ }^{(g-s)}$, in the vicinity of the point of curve intersection describing the rotational speed for two-phase mixtures: $n_{D}{ }^{(s)}=f_{1}\left(n_{G}\right)$ - for the complete suspension and $n_{G}{ }^{(g)}=f_{2}\left(n_{D}\right)$ - for complete gas dispersion in the whole vessel volume. Gas was put into the vessel below the upper impeller, when the impellers did not 
work. Next, the upper impeller was started and its rotational speed was increased to the $n_{G 1}{ }^{(g-s)}$. Then, the lower impeller was started and its rotational speed was increased to the moment $n_{D 1}{ }^{(g-s)}$, when the solid was completely suspended.

In the next move, the lower impeller rotational speed was corrected in order to achieve the requested degree of gas dispersion. If at the rotation $n_{G 1}{ }^{(g-s)}$ gas bubbles did not reach the vessel bottom, the rotation was increased, and in a different case, it was decreased, in order to have the same state for $n_{G 2}{ }^{(g-s)}$. Both impellers were stopped and the gas supply was cut-off. Then, the gas was again transferred to the vessel, and the upper impeller was started with the $n_{G 2}{ }^{(g-s)}$ rotational speed, and rotational speed of the lower impeller was increased in order to obtain a complete suspension for $n_{D 2}{ }^{(g-s)}$. This was the procedure for the moment, when in the next $i$ - approximation $n_{G i}{ }^{(g-s)}$ and $n_{D i}{ }^{(g-s)}$, were received so that:

$$
\left|\frac{n_{G i}^{(g-s)}-n_{G i-1}^{(g-s)}}{n_{G i-1}^{(g-s)}}\right| \leq 0.015
$$

and

$$
\left|\frac{n_{D i}^{(g-s)}-n_{D i-1}^{(g-s)}}{n_{D i-1}^{(g-s)}}\right| \leq 0.015
$$

As a critical impeller rotational speed $n_{G}{ }^{(g-s)^{*}}$ and $n_{D}{ }^{(g-s)^{*}}$ the arithmetical average from two last approximations was taken.

A three-phase system with phase dispersion, no worse than that in a two-phase mixture, can be produced. It is also possible to produce it with another combination of the impeller rotational speed. It was experimentally checked by choosing a rotational speed close to a critical one in the two-phase system (Fig. 3).

At the beginning, the lower impeller rotational speed was increased to a chosen $n_{D}$. Next, the gas was added below the upper impeller, they were both started and the speed of its rotation was increased to the moment, until bubbles of gas started reaching the vessel bottom, at $n_{G}{ }^{(p-s)}$. In this state, it was checked if the solid was still moving. If so, it was assumed that at such impeller rotational speed a three-phase system was obtained. The gas dispersion degree in it reached its critical value, and the solid suspension degree was not smaller than that necessary to create a complete suspension.

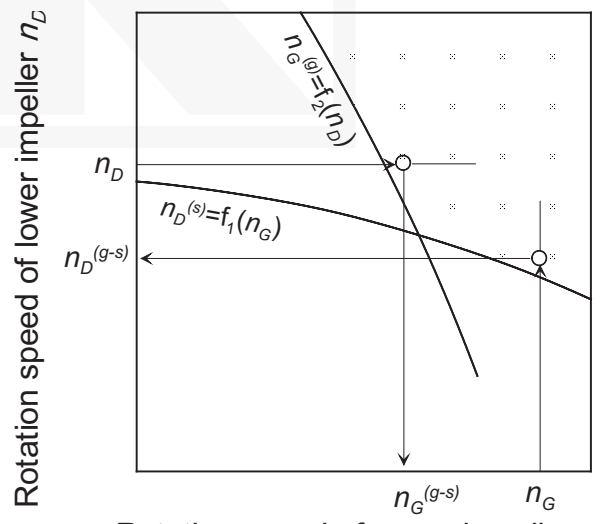

Rotation speed of upper impeller $n_{G}$

Fig. 3. Determination of the rotational speed of impellers guaranteeing to obtain a threephase system 
In the second method, gas was added below the upper impeller, with the chosen rotational speed $n_{G}$. Next, the lower impeller was started and its rotational speed was increased to $n_{D}(g-s)$, the moment when suspension was completed. For these parameters, it was checked if bubbles of gas were getting through to the vessel bottom. If this was the case, the suspension of the solid was completed and the gas was dispersed just as well as for the critical rotational speed.

The determined critical impeller speeds for the three-phase mixture were designated as $n_{D}{ }^{(g-s)}$ and $n_{G}{ }^{(g-s)}$, and are marked in Fig. 4, 5 with a "plus" $(+)$ mark.

a)

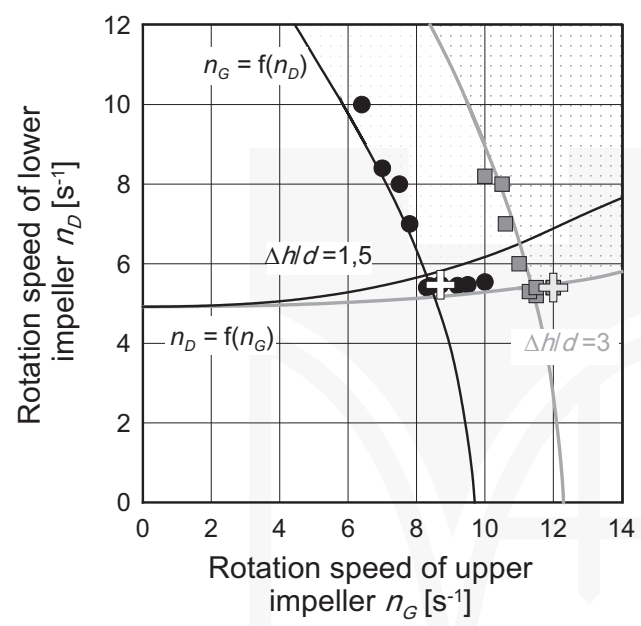

b)

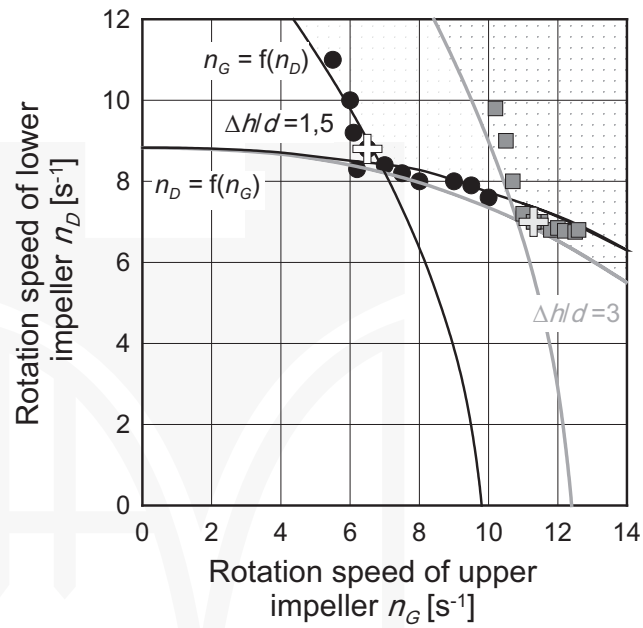

Fig. 4. Critical impeller rotational speed at creating three-phase mixture.

Consistent direction of impeller rotation; $d_{s}=0.58 \mathrm{~mm} ; w_{g}=1.067 \times 10^{-3} \mathrm{~m} / \mathrm{s}$, a) $\left.c_{m}=0.02 \mathrm{~kg} / \mathrm{kg}, \mathrm{b}\right) c_{m}=0.05 \mathrm{~kg} / \mathrm{kg}$

As can be seen, critical impeller rotational speeds for the three-phase mixture were close to the point of intersection of curves depicting analogous critical rotational speeds for the two-phase mixture. The maximum difference between them for a combination with the upper turbine Rusthon impeller did not exceed $\pm 0.7 \mathrm{~s}^{-1}$.

In a case when impellers rotate in the same direction producing a three-phase mixture, generally an increase in the rotational speed of the turbine impeller is required, compared to a two-phase system (Fig. 4a). However, the rotational speed of the lower impeller can stay on the same level (distance between impellers $\Delta h>2 d$ ), slightly decreased (if $c_{m}=0.02 \mathrm{~kg} / \mathrm{kg}$ and $\Delta h \leq 2 d$ ), or slightly increased (if $c_{m}=0.05 \mathrm{~kg} / \mathrm{kg}$ and $\Delta h \leq 2 d$ (Fig. $4 \mathrm{~b}$ ). In these cases, the increased rotational speed of the lower impeller is „compensated” by a decreased rotational speed of the upper impeller.

If impellers work with adverse direction, then regardless of the distance between them, solid particle size, their concentration and the gas flow rate. It is always necessary to increase the rotational speed of both impellers. With regard to the upper impeller, the increase is slight, although the lower impeller rotational speed depends on the size of solid particles, and it increases more when solid particles are bigger and their concentration level is higher (Fig. 5). 
a)

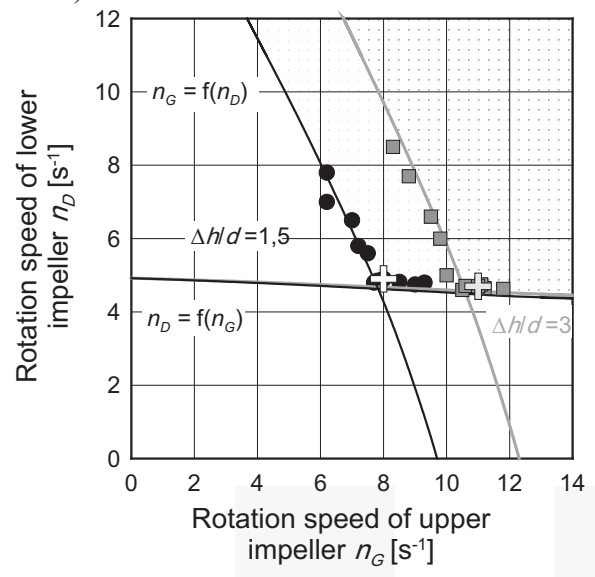

b)

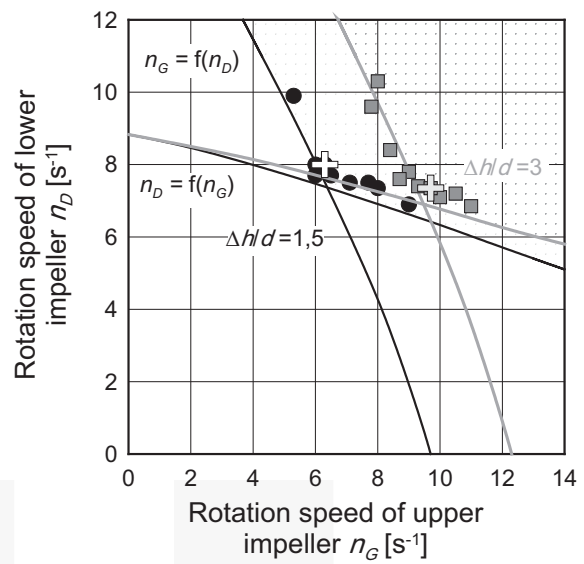

Fig. 5. Critical impeller rotational speed at creating three-phase mixture. Adverse direction of impellers rotation. $d_{s}=0.58 \mathrm{~mm} ; w_{g}=1.067 \times 10^{-3} \mathrm{~m} / \mathrm{s}$, a) $\left.c_{m}=0.02 \mathrm{~kg} / \mathrm{kg}, \mathrm{b}\right) c_{m}=0.05 \mathrm{~kg} / \mathrm{kg}$

A three-phase mixture - dispersed not worse than a two-phase mixture, can also be obtained with other combinations of impeller rotational speed. It was validated experimentally according to the way described in methods section. The obtained results were marked with different symbols, for the distance between impellers $\Delta h=1.5 d$ - with circles, and for $\Delta h=3 d$ - with squares.

Applying a higher rotational speed of the upper - turbine impeller than $n_{G}^{\left({ }^{(-s)}\right.}$ results in complete solid suspension, and gas dispersion is better than that for critical rotation - when gas bubbles reach the bottom of the vessel. Depending on the direction of the impeller rotation, the necessary rotational speeds are lower than the critical speeds, guaranteeing a complete suspension in fluid only - when both impeller directions are consistent, or higher when they are adverse. The scale of these changes is relatively small and it slightly grows along with the solid concentration.

In turn, for the rotational speed of the turbine impeller lower than $n_{G}^{(g-s)}$ the added gas stream will be dispersed into bubbles, and will reach the bottom of vessels, provided that the rotational speed of the lower impeller in relation to the critical impeller rotation needed for complete suspension of the onsolid in the liquid (Figs. 4, 5 points lying along the upper parts of the line $\left.n_{G}=f\left(n_{D}\right)\right)$. Because of that, the produced suspension in a liquid-gas mixture will be more homogeneous and particles of the solid will be getting through higher than in the two-phase mixture.

Mixing of a three-phase system should be carried out in order to get at least satisfactory dispersion of phases in a liquid. This condition can be achieved with various combinations of impeller rotational speed, starting with the lowest, lying directly close to the curves, illustrating their critical values in relation to the two-phase mixture. As "safety" and covering all the measurement combinations of process variables, it is generally possible to assume that 
the rotational speed of both impellers should be by at least $0.7 \mathrm{~s}^{-1}$ higher than the critical value for the two-phase mixture and it must be located in the hatched graph area.

Knowledge of energy expenditure allows to assess the efficiency of the process and to determine for which combinations of impeller rotational speed it is higher and for which it is lower.

a)

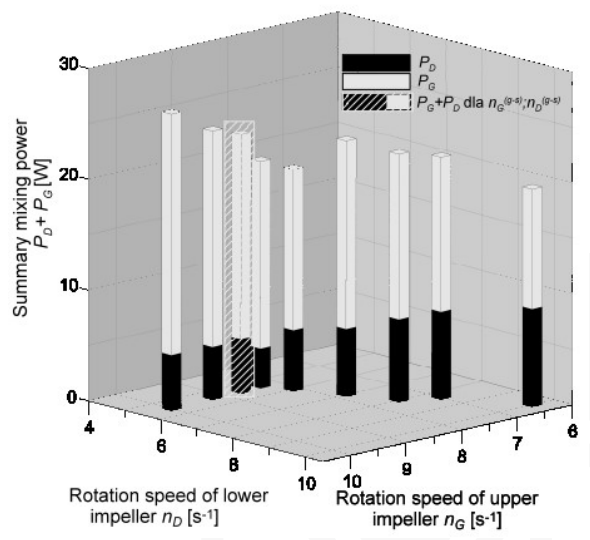

b)

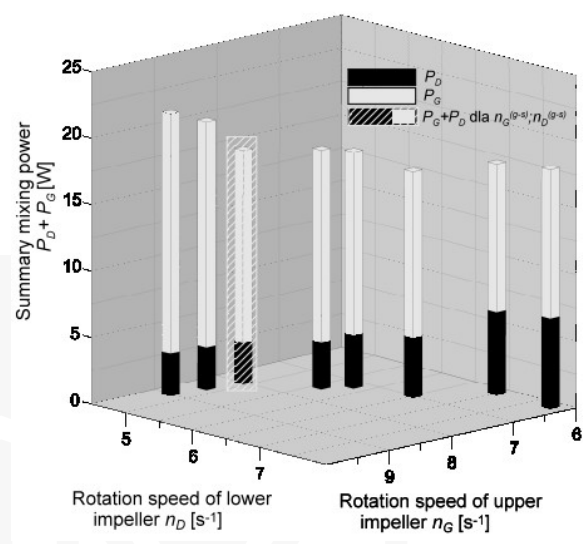

Fig. 6. Total mixing power $P_{D}+P_{G}$ dependent on impeller rotational speed. $\Delta h=1.5 d ; c_{m}=0.02 \mathrm{~kg} / \mathrm{kg} ; d_{s}=0.58 \mathrm{~mm} ; w_{g}=1.067 \times 10^{-3} \mathrm{~m} / \mathrm{s}$

Direction of impeller rotation: a) consistent, b) adverse

a)

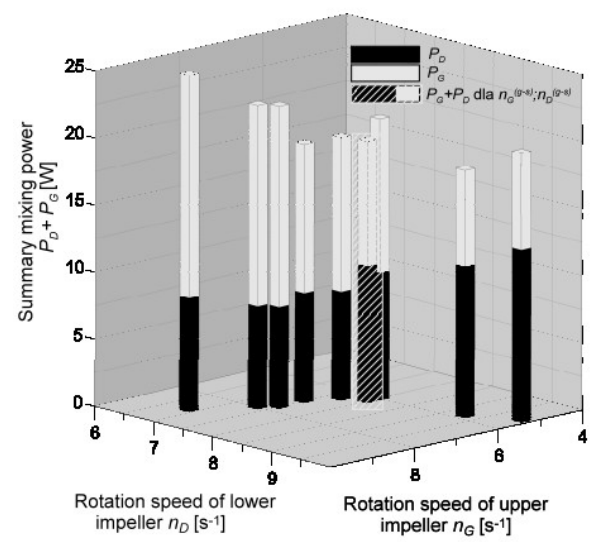

b)

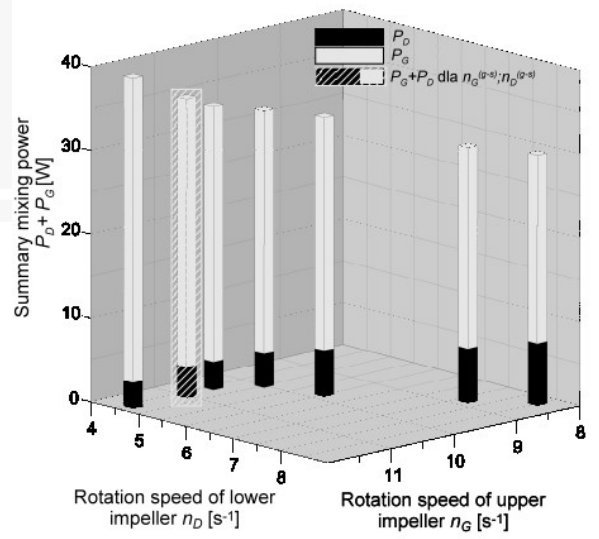

Fig. 7. Total mixing power $P_{D}+P_{G}$ dependent on impeller rotational speed $d_{s}=0.58 \mathrm{~mm} ; w_{g}=1.067 \times 10^{-3} \mathrm{~m} / \mathrm{s}$. Adverse direction of impeller rotation: $\left.\Delta h=1.5 d ; c_{m}=0.05 \mathrm{~kg} / \mathrm{kg} ; \mathrm{b}\right) c_{m}=0.02 \mathrm{~kg} / \mathrm{kg} ; \Delta h=3 d$ 
The obtained results are presented in the form of charts, showing the total mixing power, accounting for the power of each of the impellers (Figs 6,7). Summary mixing power for critical impeller rotation $n_{G}{ }^{(g-s)^{*}}$ and $n_{D}{ }^{(g-s)^{*}}$ was denoted by shading the columns. Other columns on this graph present summary mixing power for other impeller speed combinations, corresponding to the points in Figs. 4, 5, which were found to be sufficient for obtaining a three-phase mixture.

If the impellers rotation is consistent, in order to obtain a three-phase system, we need a higher rotational speed than that for an adverse rotational direction. The total mixing power is also greater, and the lower impeller has a greater participation. The lowest mixing power was found for the rotational speed corresponding to the points in the middle of the chart. At the designated critical rotational speed $n_{G}^{(g-s)^{*}}$ and $n_{D}(g-s)^{*}$ the total mixing power was the highest. An increase of one impeller rotational speed and an appropriate correction of the rotational speed of the second impeller results in an increase of the total mixing power.

In the case of an adverse direction of the impeller rotation, at a lower concentration of the solid, their total mixing power with the critical impeller speed $n_{G}{ }^{(g-s)^{*}}$ and $n_{D}(g-s)^{*}$ was not the lowest of all measured. A three-phase mixture with a good, or even better dispersion of one of the phases can be obtained for another impeller rotational speed and lower power input. From the point of view of mixing process efficiency, the process should be conducted with such combinations of the impeller rotational speed that lie to the left of the common point discussed above the curves. Thus, it is better when $n_{G}<n_{G}^{(g-s)^{*}}$, and $n_{D} \geq n_{D}{ }^{(g-s)}$. These changes are not equal to the value because the upper turbine impeller is much more "energy-consuming" than the lower A-315; therefore, the total mixing power decreases.

\section{Conclusions}

Critical impeller rotational speeds necessary to produce a three-phase mixture are in general a little bit higher than those required for obtaining solid-liquid and gas-liquid mixtures. However, they do not differ significantly from them.

Taking into account mixing efficiency, it is advantageous when rotational directions of impellers are adverse to each other. Then, the critical rotational speed is lower compared to the consistent rotation.

It is possible to produce a three-phase system when impeller rotational speeds are in the area above the rotational speed curve assigned for a two-phase mixture: $n_{D}{ }^{(s)}=f_{1}\left(n_{G}\right)$, $n_{G}^{(g)}=f_{2}\left(n_{D}\right)$.

At the critical impeller rotational speed $n_{G}{ }^{(g-s)^{*}}$ and $n_{D}{ }^{(g-s)^{*}}$ their total mixing power was not the lowest for all the measured values for this set of impellers. From the point of view of the mixing efficiency, it is advantageous to apply lower than critical speeds of turbine impeller $n_{G}<n_{G}{ }^{(g-s)^{*}}$, and higher A-315 impeller $-n_{D} \geq n_{D}{ }^{(g-s)^{*}}$. 


\section{Notation}

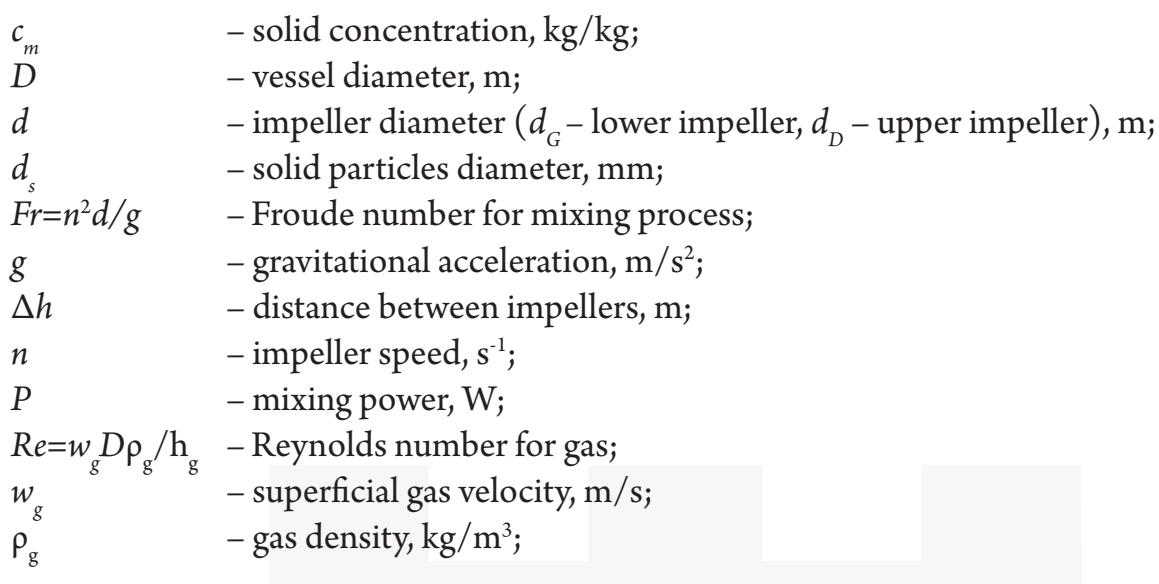

\begin{tabular}{|c|c|c|c|}
\hline \multicolumn{2}{|c|}{ Subscripts } & \multicolumn{2}{c|}{ Superscripts } \\
\hline D & - refers to lower impeller; & $(s)$ & - just drawdown; \\
\hline$D 1$ & - refers to lower impeller and $n_{G}=0 ;$ & $(g)$ & - refers to the gas-liquid system; \\
\hline G & - refers to upper impeller; & $(g-s)$ & - just drawdown under gassed \\
\hline$G 1$ & - refers to upper impeller and $n_{D}=0 ;$ & & Conditions. \\
\hline
\end{tabular}

\section{References}

[1] Kamieński J., Spytkowski S., Efektywność wytwarzania zawiesiny w smuktym aparacie, Inżynieria i Aparatura Chemiczna, Vol. 48 (6), 2009, 95-96.

[2] Kamieński J., Spytkowski S., Wytwarzanie zawiesin ciała statego w aparacie $z$ dwoma mieszadtami, Przemysł Chemiczny, Vol. 89 (2), 2010, 164-168.

[3] Kamieński J., Spytkowski S., Dyspergowanie gazu w cieczy w aparacie $z$ dwoma oddzielnie napędzanymi mieszadtami, Inżynieria i Aparatura Chemiczna, Vol. 50 (4), 2011, $26-27$.

[4] Kamieński J., Rozpraszanie gazu w cieczy z użyciem dwóch indywidualnie napędzanych mieszadet, Czasopismo Techniczne 2-M /2012, 55-162.

[5] Spytkowski S., Analiza pracy mieszalnika układów wielofazowych $z$ niezależnie napędzanymi mieszadłami, Ph.D. dissertation, Politechnika Krakowska, Kraków 2014.

[6] Micale G., Carrara V., Grisafi F., Brucato A., Solid suspension in three-phase stirred tank, Chemical Engineering Research \& Design, Vol. 78, 2000, 319-326. 
[7] Karcz J., Kiełbus A., Postępy w badaniach mieszanego mechanicznie układu tróffazowego ciecz-gaz-ciało stałe, Inżynieria i Aparatura Chemiczna, Vol. 42 (5), 2003, 84-85.

[8] Jafri R., Tanguy P. A., Chaouki J., Experimental investigation on solid dispersion, power consumption and scale-up in moderate to dense solid-liquid suspensions, Chemical Engineering Research \& Design, Vol. 90 (2), 2012, 201-212.

[9] Ayranci I., Kresta S. M., Critical analysis of Zwietering correlation for solids suspension in stirred tanks, Chemical Engineering Research \& Design, Vol. 92 (3), 2014, 413-422. 


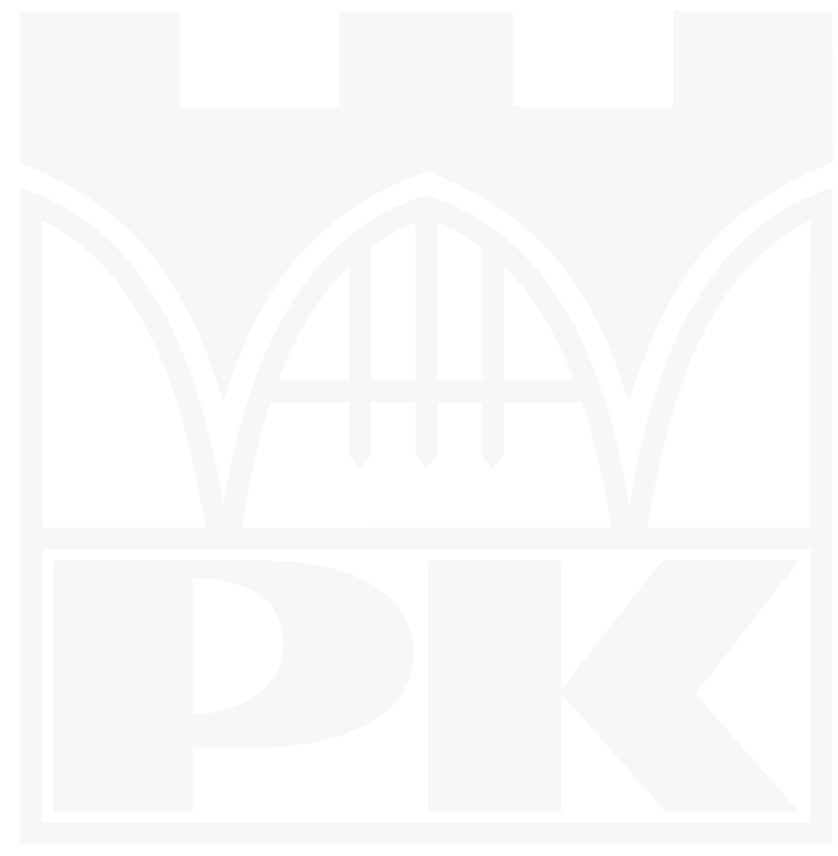

